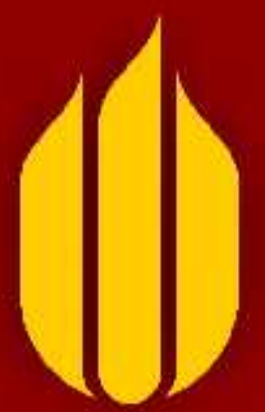

U N I VERS I TAS MERCU BUANA Y O G Y A K A R T A

Program Studi Akuntansi Fakultas Ekonomi Universitas Mercu Buana Yogyakarta Jl. Wates Km. 10 Sedayu Bantul Yogyakarta 55753 Telp. (0274) 6498212 ext. 145. Fax. (0274) 6498213 email : jurnal.umby@gmail.com

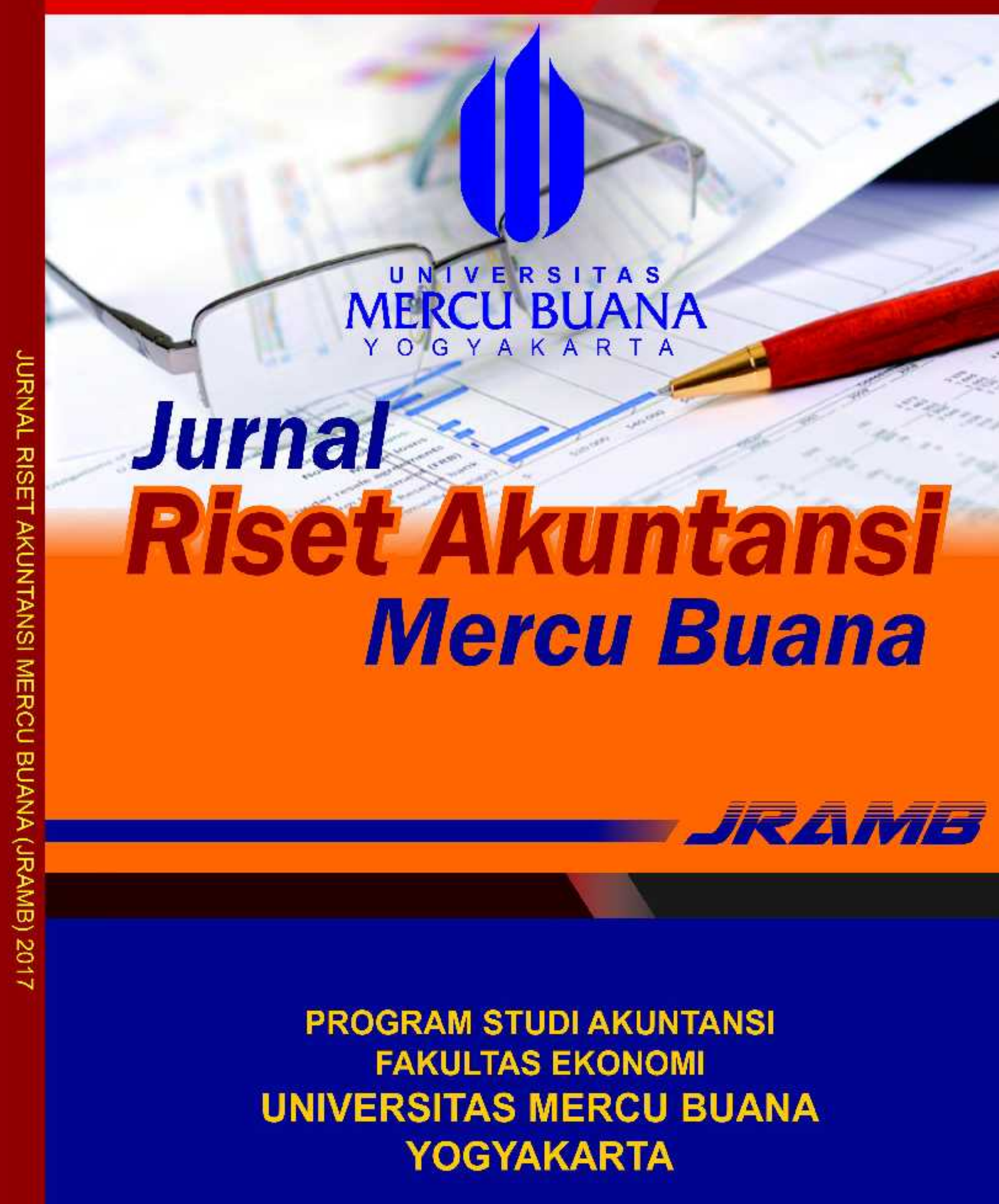




\title{
PEMIMPIN REDAKSI
}

Tutut Dewi Astuti, S.E., M.Si., Ak., CA., CTA.

\author{
SEKRETARIS REDAKSI \\ Rochmad Bayu Utomo, S.E., M.Si., Ak., CA. \\ Zaenal Wafa, S.Kom., M.Kom.
}

\section{DEWAN REDAKSI}

Prof. Dr. Indra Bastian, MBA., CMA., Akt. (Universitas Gadjah Mada Yogyakarta)

Dr. Greg Shailer, B.Com., M.Com., FCPA. (The Australian National University Canbera)

Dr. Harun Harun, M.Acc., CA. (University of Canberra)

Dr. Sri Suryaningsum, M.Si., Ak., CA. (Universitas Pembangunan Nasional Veteran)

Wisnu Haryo Pramudya, S.E., M.Si., Ak., CA. (Akademi Akuntansi YKPN)

Tutut Dewi Astuti, S.E., M.Si., Ak., CA. (Universitas Mercu Buana Yogyakarta)

Nugraeni, S.E., M.Sc. (Universitas Mercu Buana Yogyakarta)

Endang Sri Utami, S.E., M.Si., Akt., CA. (Universitas Mercu Buana Yogyakarta)

Hasim As'ari, S.E., M.M. (Universitas Mercu Buana Yogyakarta)

M. Budiantara, S.E., M.Si., Ak., CA. (Universitas Mercu Buana Yogyakarta)

Mushawir, S.E., M.M. (Universitas Mercu Buana Yogyakarta)

\section{ADMINISTRASI DAN SIRKULASI}

Achmad Farid Firsalam, S.Pd.

Hamdasih Dayu Primadara, S.E.

ALAMAT REDAKSI

Pusat Pengembangan Akuntansi

Universitas Mercu Buana Yogyakarta

Jalan Wates km. 10

Yogyakarta 55753

Telpon (0274) 6498212 pesawat 145

Fax (0274) 6498213

http://ejurnal.mercubuana-yogya.ac.id/

Email: jurnal.umby@gmail.com

Jurnal Riset Akuntansi Mercu Buana (JRAMB) diterbitkan oleh Unit Publikasi Ilmiah \& HaKI Universitas Mercu Buana Yogyakarta, dimaksudkan sebagai media pertukaran informasi dan hasil penelitian antara staf pengajar, alumni, mahasiswa.

JRAMB terbit dua kali setahun.

Redaksi menerima naskah yang belum pernah dipublikasikan. Pedoman penulisan naskah untuk

JRAMB tercantum pada bagian akhir jurnal ini.

Surat-menyurat mengenai artikel yang akan diterbitkan, langganan, keagenan dll, dialamatkan langsung ke alamat redaksi. 


\title{
MERCU BUANA \\ YOGVAKARTA
}

JURNAL RISET AKUNTANSI MERCU BUANA (JRAMB)

Pusat Pengembangan Akuntansi

Universitas Mercu Buana Yogyakarta

\author{
Sekretariat: Jalan Wates Km. 10 Yogyakarta, \\ telpon (0274)6498212 pesawat 144 \\ email: jurnal.umby@gmail.com \\ web: www.mercubuana-yogya.ac.id
}

\section{KATA PENGANTAR}

Puji syukur kami panjatkan ke hadirat Tuhan Yang Maha Esa, karena atas berkat rahmat-Nya kami bisa menyelesaikan Jurnal Riset Akuntansi Mercu Buana Edisi Volume 3 Nomor 1 Tahun 2017.

Kami mengucapkan banyak terima kasih kepada semua pihak yang telah membantu, sehingga jurnal edisi Volume 3 Nomor 1 Tahun 2017 dapat diterbitkan.

Redaksi menyadari bahwa jurnal edisi ini masih jauh dari sempurna, oleh karena itu, kritik dan saran yang bersifat membangun sangat kami harapkan demi sempurnanya jurnal ini.

Semoga jurnal ini memberikan informasi bagi masyarakat dan bermanfaat untuk pengembangan wawasan dan peningkatan ilmu pengetahuan bagi kita semua. 
DAFTAR ISI

KATA PENGANTAR $\mathrm{i}$

Analisis Pengukuran Kinerja Rumah Sakit Dengan Pendekatan balanced Scorecard Pada Rumah Sakit Daerah Madani Palu Tahun 2015

Olivia H. Munayang, Ririn Parmita, Andini Nurhajra

Kajian Kemampuan Keuangan Daerah Untuk Pertimbangan Penempatan Modal Daerah Pada BUMD (Studi Kasus Apbd Pemerintah Kabupaten Cianjur)

Sjamsuridjal, Abin Suarsa.

Pengaruh Brand Ambassador Dian Sastrowardoyo Terhadap Brand Image

Produk Makeup L'oreal Paris(Studi Pada Konsumen L'oreal Kota Bandung)

Dina Arti Masyita, Ai Lili Yuliati.

Pengaruh Brand Image Terhadap Keputusan Pembelian Produk Adidas Di Paris Van Java Bandung

Dyah Ayu Lestari, Ida Nurnida $48-56$

Prediksi Harga Saham PT. Astra agro lestari tbk Dengan Jump Diffusion Model

Di Asih I Maruddani, Trimono 57-67 


\section{PEDOMAN PENULISAN NASKAH}

Naskah artikel yang diterima adalah hasil penelitian, naskah ditulis dalam Bahasa Indonesia, ukuran A4 - dua Kolom, diketik dengan font Times New Roman size 11. Jarak antar baris 1,5 spasi maksimal 20 halaman termasuk grafik, gambar dan tabel. Naskah diserahkan dalam bentuk softcopy.

Gambar (garis \& foto) dan tabel diberi nomer urut sesuai dengan letaknya. Masing-masing diberi keterangan singkat dengan nomor urut dan dituliskan di luar bidang gambar yang akan dicetak.

Nama ilmiah dan bahasa asing dicetak miring. Rumus persamaan ilmu pasti, simbol dan lambang semiotik ditulis dengan jelas.

Susunan urutan naskah ditulis sebagai berikut:

1. Judul dalam Bahasa Indonesia dan Bahasa Inggris.

2. Nama penulis tanpa gelar diikuti alamat institusi dan alamat email.

3. Abstrak dalam Bahasa Indonesia dan Bahasa Inggris, terdiri dari 1 paragraf dan tidak melebihi 250 kata. (font Times New Roman size 10. Jarak antar baris 1 spasi)

4. Materi dan Metode.

5. Hasil dan Pembahasan.

6. Kesimpulan.

7. Daftar Pustaka ditulis menggunakan sistem nama, tahun dan disusun secara abjad.

Beberapa contoh:

1. Rujukan dari Buku

Creswell, J. W. (1998). Qualitative inquiry and research design: Choosing among five traditions. Thousand Oaks. California: Sage Publications, Inc.

\section{Rujukan dari artikel dalam jurnal} ilmiah

Quintanilla-Ruiz, S. A., \& Wilpert, B. (1991). Are Work Meanings Changing? Eroupean Work and
Organizational Psychologist, 1, $91-109$.

3. Rujukan dari artikel dalam buku kumpulan artikel

Alwassilah, A. Chaedar. (2009). Metodologi Pembelajaran Bahasa yang Profesional. Dalam Hasanuddin \& Ermanto (Eds.), Prosiding Seminar nasional: Pengembangan Pendidikan dan Pembelajaran Bahasa dan Sastra Indonesia dalam Peningkatan Profesionalisme Guru (hlm. 1-9). Padang: Citra Budaya Indonesia.

4. Rujukan dari laporan Penelitian, Skripsi, Tesis atau Disertasi

Gatot, R. Y. (1999). Motivasi kerja buruh gendong dalam meningkatkan ketahanan keluarga (Studi penelitian di Pasar Beringharjo Kodya Yogyakarta DIY). Thesis. Universitas Gadjah Mada, Yogyakarta, Indonesia.

5. Rujukan dari Makalah Seminar, Penataran, Lokakarya.

Huda, N. (1991). Penulisan laporan Penelitian untuk Jurnal. Makalah disajikan dalam Lokakarya Penelitian Tingkat Dasar bagi Dosen PTN dan PTS di Malang, Pusat Penelitian IKIP Malang, Malang, 12 Juli.

\section{Rujukan Artikel dari Online}

Safarian, \& Saputra. (2006). Rancangan arsitektur klub Purna Bakti PT. Telkom di Surabaya. [Online]. Available http://digilib.petra.ac.id/klub_pu rna-chapter3.pdf. diakses 12 Maret 2008.

Redaksi berhak menyusun naskah agar sesuai dengan peraturan pemuatan naskah atau mengembalikannya untuk diperbaiki, atau menolak naskah yang bersangkutan. 